\title{
APPLICATION OF TOPSIS METHOD FOR THE EVALUATION OF ECONOMIC INEQUALITY IN OECD COUNTRIES
}

\begin{abstract}
Growing economic stratification each year in many countries is such a pressing issue that even the World Economic Forum, organized in 2014 in the luxury resort of Davos, recognized it as one of the most dangerous threats to social order. The problem of economic inequality, pushed by the apologists of economic liberalism to the margins of media discourse, once again became a "hot" topic with the World Economic Crisis in 2008, the effects of which are still felt in various countries today, and which contribute to the expansion of global social stratification.

The aim of the article is to describe the sample indicators typically used by organizations, i.e. OECD, the World Bank to measure economic inequality in the world, and then, on the basis of these indicators, create a synthetic instrument based on TOPSIS methodology, which will allow for preparing a multi-criteria ranking of OECD countries in terms of economic inequality.

Keywords: economic inequality, income inequality, TOPSIS method.
\end{abstract}

\section{Growing economic inequality from a global perspective}

The issue of progressive economic inequality (material and income inequality) was virtually absent from the public debate during the last two decades. Of course, the media, political, and social discourse addressed the consequences of this phenomenon described through the prism of access to quality education, to the labor market, the progressive differentiation of living conditions, social mobility, and increasing consumer debt of poorer social groups. However, very rarely did they treat economic inequality as the main source of these phenomena. They explained them rather as the inevitable consequences of capitalism and the free market, which increases the disparities between individuals and social groups, but is made in a justified way, as it happens according to meritocratic rules. This thought was supported by sociologists, claiming that the market "(...) is essentially a meritocracy, that is, levelling the playing field (...) giving the chance for the better ones" 
(W. Woźniak, 2013). Social inequalities tend to be fair, if the necessary condition is met: "reward" is proportional to "contribution", or in other words "for each one according to the merit", and in the market economies the valuation of merit is determined by the market (W. Woźniak, 2013).

Growing income inequality, in a period of dynamic economic growth, was explained by neoclassical theory or economic concepts such as the Kuznets curve, which assumed that in a period of intensive growth of the economy, economic inequality will also inevitably increase (J. Galbraith, 2007). No implied correlation had been proved to S. Kuznets already in the 1990s (G. Fields, 2001). This was done by specialists from the World Bank, the institution that was the loudest advocate and biggest ally of liberal changes in the economy. A few scientists (e.g. T. Kowalik, M. Bruno, and L. Suire and M. Ravalliona) stood in opposition to the neo-liberal assumptions trying to prove that the dilemma of "equality or economic growth" is false (W. Woźniak, 2013). Recent OECD analysis (e.g. "How Was Life? Global Well-being since 1820") fits in with their reasoning and provides empirical evidence.

Another concept, marginalizing in its assumptions issues of social distance, was mentioned earlier trickle-down theory, very popular in the eighties of the twentieth century, and described with the phrase "the tide lifts all boats." This concept proved that supposedly, the increase of wealth at the top of the hierarchy of the income of society, at some unidentified point will "go down" to the lower layers. The scientific foundation of this theory was the controversial concept of the Laffer curve (I. B. Tucker, 2010, p. 241), according to which a significant tax increase would reduce budget revenues. This relationship actually exists, but it applies to specific cases - to indirect taxes in particular.

However, as shown by the historical data (T. Piketty, 2014), prosperity somehow did not want to drip down into the lower layers. According to official data of the Congress Budget Office, in the period from 1977 to 1987, family income of the bottom 10\%, after tax, calculated in dollars in 1987 fell by $10.5 \%$, the average income of the top $10 \%$ of families increased by $24.4 \%$, and the income of $1 \%$ of families with the highest income grew by $74.2 \%$ (Kęcik, 2012). The dominance of the highest class has been strengthened. Since the implementation of neoliberal policies, the share of the richest $1 \%$ of Americans in the national income has increased by 2000 from less than $8 \%$ to $20 \%$. The share of $0.1 \%$ of the population with the highest income increased from $2 \%$ in 1978 to over $6 \%$ in 1999. The ratio of salaries of CEOs to median earnings of workers changed from 30: 1 in 1970 to almost 400: 1 in $2000^{1}$. 
Figure 1. The share of income of the upper percentile in the total income

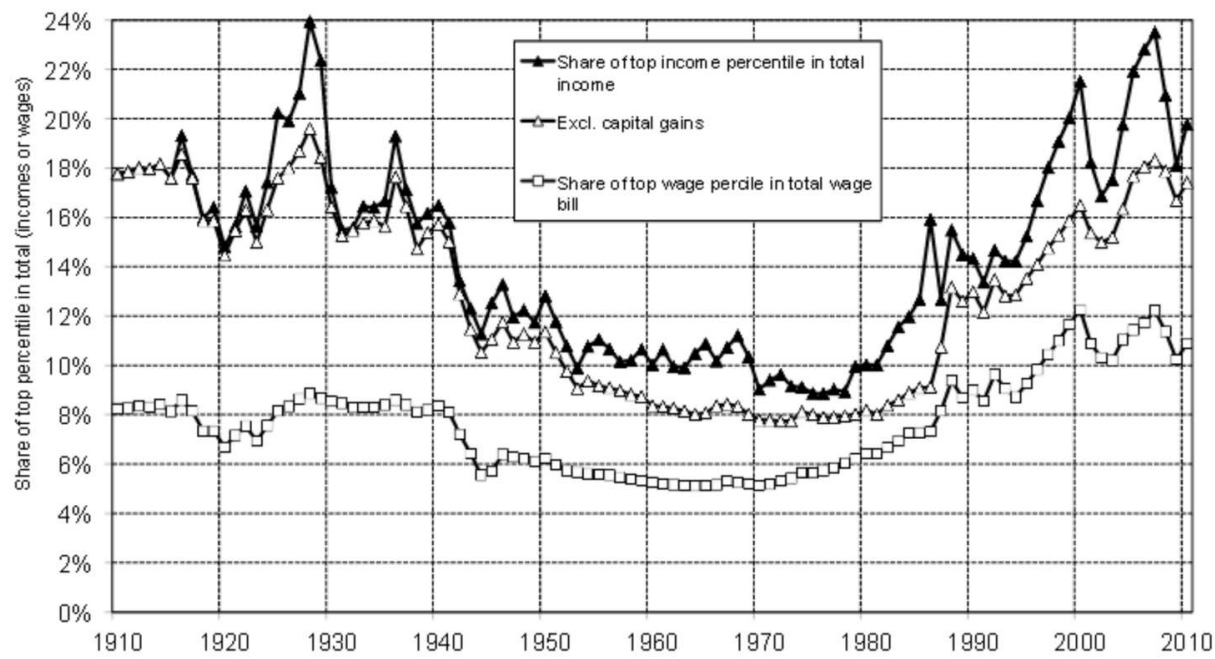

Source: based on T. Piketty, http://piketty.pse.ens.fr/files/capital21c/en/pdf/F8.8.pdf, access [03.06.2016].

Economic changes during the Reagan presidency opened the way to capitalism deprived of effective control mechanisms, aimed primarily at profit, which was perfect for clever bankers and speculators. The result of the deregulation of markets, combined with the activities of financial institutions, was a significant increase in the amount of stock market speculation and the emergence of so-called "Gray banking" ${ }^{2}$. The first noticeable global effect of these actions was "Black Monday" in 1987, still under the Reagan presidency, when there was an unexpected crash on the New York Stock Exchange. The Dow Jones index soared down by $22 \%$, and nearly 560 billion dollars disappeared from the market within one day. It was the largest percentage drop in the history of this index. These events did not affect the actions of politicians, and the fundamental principles of neoliberalism were adopted both by George Bush in the US and by Tony Blair in Britain. It was not until the next global financial crisis at the end of 2007 that the world realized the risks arising from a lack of proper control over the system.

In the United States, the distance between the 1\% richest class, a middle class threatened with economic collapse and the poor is constantly growing and, according to the authors of a growing number of scientific studies (JE Stiglitz, 2012; N. Klein, 2002; T. Piketty, 2014; R. Wilkinson K. Pickett, 2009 G. Therborn, 2013 Lal), politicians, above all, have in mind the benefit of corporations and financial circles. Now, the injustices are protested 
against in many countries - the movement "The Indignants" claims to be representative of society, robbed of life chances.

Similar ignorance of issues of inequality prevailed in most of the public debates in European countries, but economic stratification (material and income) is constantly expanding, and despite the fact that it did not reach the size of the US, it shows the progressive upward trend that was begun by deregulation of the economy made by R. Reagan and M. Thatcher (Figure 2).

Figure 2. The share of income of the top decile: selected countries in Europe and the US, 1900-2010

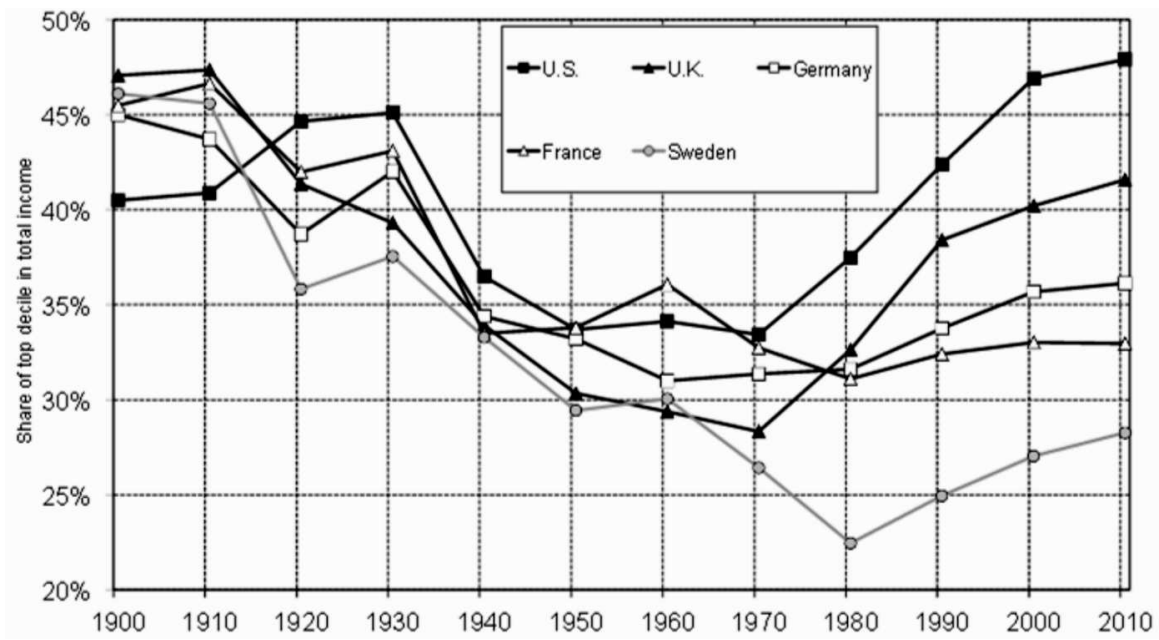

Source: T. Piketty, http://piketty.pse.ens.fr/files/capital21c/en/pdf/F9.7.pdf [access: 03.10.2015]

It was not until the collapse of the world economy in 2008, which significantly affected Europe, that a change in the mood among politicians took place and the words of economists - who once accused the left-wing of defeatism and obstructionism - were confirmed (Krugman P., J. E. Stiglitz, D. Rodrik, N. Roubini). Their studies, due to the accuracy of predictions being made even before the crisis, have begun to return to the discourse of political debate. In addition, the public began to reach the message coming from the studies of non-economic society researchers (G. Therborn, 2013; R. Wilkinson and K. Pickett, 2009). Thanks to their analysis, problems of social and economic inequality again have become an important topic on the political agenda.

The average income of the richest in the past decades, in most OECD countries, has steadily increased, while earnings of the poorest $10 \%$ are 
growing much more slowly in the years of prosperity and fall during the downturn, to the extent that the rate of poverty has become a pressing issue of social policy in many countries of the organization. Wealthy people in terms of wealth held, leave the rest of society behind at an accelerating pace. The World Top Incomes Database covers 43 countries, where information is collected on the share of income before tax, which has gone to the richest one per cent from the year 1980 (http://www.wid.world [access: 08.07.2015]). In all countries, except for Colombia and the Netherlands, the share of income of the richest percentile went up. Since 1980, the richest one percent of people in China, Portugal and the USA doubled its share in the national income. Even in more egalitarian countries such as Sweden and Norway, the share of revenues flowing to the richest one percent rose by more than 50 percent (F. Alvaredo, et.al., 2013).

An Oxfam report presents converging data "Working for the few. Political capture and economic inequality" (https://www.oxfam.org/en/research/ working-few [access: 03.02.2014]). In a public report the authors express concern that stratification of wages left without control leads to irreversible consequences and a subsequent "capture of opportunities" by the wealthiest. This taking advantage of opportunities relates to such a state of affairs where the most favorable tax rates, the best education, health care, the best products and services are reserved for the rich and their children. This creates a dynamic and mutual series of benefits that are passed on from generation to generation. According to the authors, given the scale of increase in the concentration of wealth and the capturing of possibilities by the rich, unequal political representation has created a noticeable and disturbing trend ${ }^{4}$.

\section{How to measure economic inequality}

The calculation of inequality is measured by data on the stratification of income defined by various indicators. The most popular indicators include the Gini coefficient and the ratio of the income of the highest decile or percentile group to the income of the lowest decile or percentile group (i.e., the position of the income of the richest group in relation to the poorest). These indicators are easily readable and interpretable. The Gini index is created using the Lorenz curve, which examines what percentage of the population gets a given percentage of income. Therefore, it remains a growing curve. In an egalitarian society a Lorenz curve runs at an angle of 45 degrees. Then, for example, $50 \%$ of the population get $50 \%$ of revenues. However, the larger the angle of "deformation", the income inequality in 
society is higher. Gini index is calculated on the basis of ratio of the size of area $\mathrm{A}$ to the sum of areas $\mathrm{A}$ and $\mathrm{B}$ on the diagram of Lorenz curve (Figure 3).

Standardized Gini index reaches a value from 0 to 100, where 0 means complete lack of inequality (egalitarian society), and the higher the index value, the inequalities are greater (Cowell 2009, p. 25).

Figure 3. Lorenz Curve and Gini index

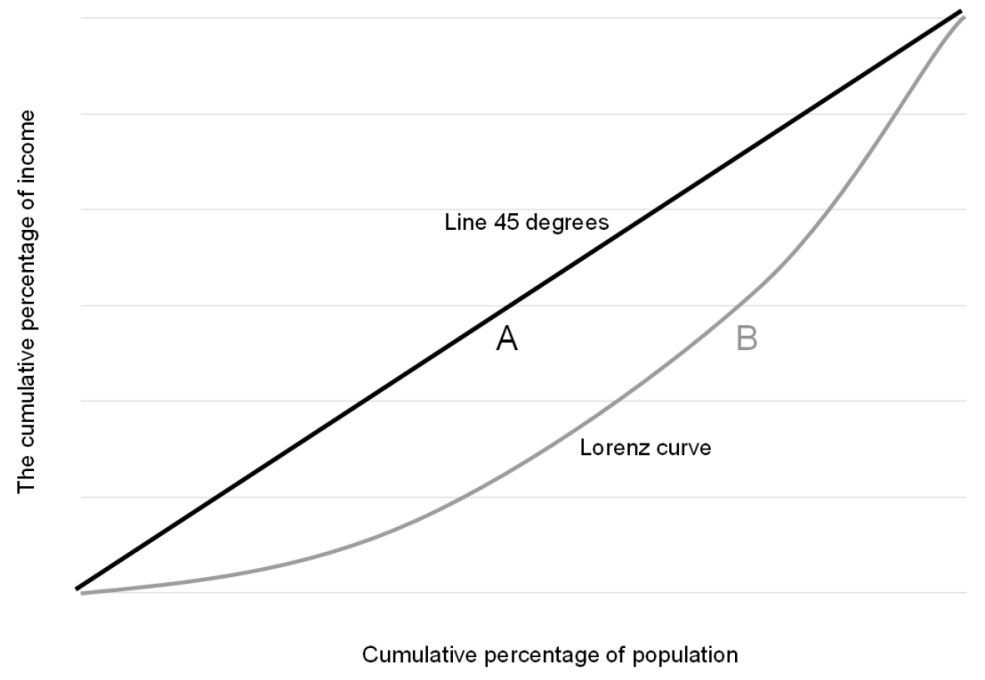

Source: own study

However, the Gini coefficient has a drawback - it is easily decomposed into sub-groups of the population surveyed (P. J. Lambert, 1993, p. 46). In other words, we are not able (in this case) to answer the question: what part of a social subgroup is "responsible" for general social inequality. Theil index is a measure which allows that - which is a particular case of a wider group of measurement (Shorrocks A.F., 1980, p. 613-625), which has an important feature called additive decomposability. Using the Theil index, we can decompose overall inequality into subgroups and determine the "contribution" of these subgroups in the development of overall inequality.

Theil exploited the fact that ownership of shares of individuals in the total value of the variable $X$ are similar to those of ownership incidence. He proposed entropy to describe and assess the inequality of the shares. It is known that entropy takes the maximum value equal to the logarithm of the number of values for uniform distribution, and so in this case, equal division when there is no concentration, and the shares of all individuals are the same. Entropy of shares may therefore be a measure of equality, not 
inequality. Theil proposed the following parameter as a measure of inequality or concentration:

$$
T(X)=\frac{1}{N} \sum_{i=1}^{N} \frac{x_{i}}{E(X)} \ln \frac{x_{i}}{E(X)}
$$

where: $X_{i}$ - income (expense) and this statistical unit (person, household), $E(X)$ - the average income (expense) of the tested $n$-element community.

Theil index can be decomposed as follows:

$$
T(X)=\frac{1}{N} \sum_{i=1}^{k} w_{k} T_{k}+T_{B}
$$

where: $w_{k}$ - coefficient of decomposition, $T_{k}$ - Theil index defined for the $k$-of this sub-group (intra group), $T_{B}$ - Theil index calculated on the basis of average values of each group (inter-group).

The above decomposition coefficient for the $k$-of this group is defined by the formula:

$$
w_{k}=\frac{n_{k} E(X)_{k}}{n E(X)} .
$$

The Organization for Economic Co-operation and Development (OECD) developed its own indicators and benchmark to monitor the situation in individual countries with respect to income inequality. This is for instance the decile income range of the population (90/10). It involves the division of society according to the level of wealth (the creation of groups), and then determining what percentage of the total income goes to the group. This method divides the population into ten groups. The first decile (first 10\%) is represented by the poorest part of the population, and the last decile by the richest (last 10\%). Comparing the marginal decile span, a span of profitability is obtained.

However, with various indicators of economic stratification it is difficult to make an unambiguous classification of the analyzed countries, since a large amount of information becomes unreadable and hardly interpretable (see Table 2).

Hence, there is need to synthesize variables often not comparable with each other in easily interpreted measure, which will verify whether the argument put by investigators (JE Stiglitz, 2012; N. Klein, 2002; T. Piketty, 2014; R. Wilkinson and K. Pickett, 2009 G. Therborn, 2013; Lal, 2015) and for enlarging inequality in rich countries like the US is confirmed.

The analytical procedure by which ranking of OECD countries is created is presented below. 


\section{Ranking of OECD countries concerning economic stratification using the topsis method}

The ranking of OECD countries was prepared by the TOPSIS method (Technique for Order Preference by Similarity to Ideal Solution), which was originally developed by Hwang and Yoon in 1981 (C.L. Hwang, K. Yoon, 1981). The aim of the analysis is to assess the level of differentiation of OECD countries in terms of economic diversification, characterized by a set of indicators available in the database of the OECD and the grouping of countries in clusters with similar characteristics (properties). TOPSIS method (T. Trzaskalik, 2008) is used to solve problems where multi-criteria issues occur. This method assumes a linear arrangement of objects (in this case - the countries included in OECD) involving the calculation of the distance between the model and anti-model. Using the designated synthetic measure it is possible to organize (ranking) tested objects described by many indicators. Characteristics and next steps of the analytical procedure are listed below.

1. Selection of variables (arbitrary): A comparative study of the OECD countries assessing economic differentiation was made on the basis of statistical data available in public sources (databases of OECD) ${ }^{5}$. According to the research assumptions, the analysis uses the indicators used in the area for the distribution of income and poverty. In addition, the information obtained from the databases of the OECD was supplemented by an indicator of the amount of tax paid by the richest people (earnings over 300 thousand dollars) in the various countries of the organization on the basis of the KPMG report 6 .

Table 1

\section{Selected indicators of differentiation}

\begin{tabular}{|l|l|}
\hline Area of analysis & \multicolumn{1}{c|}{ Number and description of indicator } \\
\hline Economic & $\begin{array}{l}\text { 1.1. Gini coefficient } \\
\text { stratification }\end{array}$ \\
& $\begin{array}{l}\text { 1.2. The tax for the richest people earning more than } 300 \text { thousand } \\
\text { dollars annually } \\
\text { income decile group } \\
\text { 1.4. The share of income of the highest decile in total income } \\
\text { 1.5. The income poverty rate }\end{array}$ \\
\hline
\end{tabular}

It should be noted that these indicators do not exhaust the range of possible use in the analysis of variables related to economic inequality. However, 
the OECD database does not include other complementary data relating to this phenomenon.

The ranking of countries for current information (from 2011-2013) was made as the first one.

\section{Calculation of the variation indicator $\mathrm{V}$ and elimination of} indicators: The procedure of ranking was started with defining the coefficient of variation $V=\frac{D(x)}{E(X)}$, where: $D(x)=\sqrt{\frac{\sum_{i=1}^{m}\left(x_{i}-\bar{x}\right)^{2}}{m}}$ is standard deviation, $E(X)=\frac{\sum_{i=1}^{m} x_{i}}{m}$ is the arithmetic mean for $(m-$ number of countries) for all indicators selected to describe states. Indicators whose variation is less than $10 \%\left(V^{*}<10 \%\right.$ - conventional value) are eliminated due to the weak impact on designated positions in the ranking. Table 2 contains the results of calculations for data from 2011-2013.

Table 2

Indicators of stratification and poverty

\begin{tabular}{|c|c|c|c|c|c|}
\hline & \multirow[b]{2}{*}{$\begin{array}{c}\text { Gini } \\
\text { coefficient }\end{array}$} & \multirow{2}{*}{\multicolumn{2}{|c|}{\begin{tabular}{|c|c|} 
Taxes for & $\begin{array}{c}\text { The ratio of the } \\
\text { income of the } \\
\text { highest decile } \\
\text { group to the } \\
\text { income of the } \\
\text { lowest decile } \\
\text { group }\end{array}$ \\
\end{tabular}}} & \multirow[b]{2}{*}{$\begin{array}{l}\text { The share of } \\
\text { income of the } \\
\text { highest decile } \\
\text { group in total } \\
\text { income }\end{array}$} & \multirow[b]{2}{*}{$\begin{array}{l}\text { The income } \\
\text { poverty rate } \\
\text { (Relative } \\
\text { threshold) }\end{array}$} \\
\hline & & & & & \\
\hline & \multicolumn{5}{|c|}{2011 or a later year available } \\
\hline Australia & 32 & 37,7 & 8,5 & 24,4 & 13,8 \\
\hline Austria & 28 & 41,8 & 7,1 & 22,2 & 9,0 \\
\hline \begin{tabular}{|l|} 
Belgium \\
\end{tabular} & 26 & 53,0 & 5,8 & 20,8 & 9,5 \\
\hline Chile & 50 & 34,6 & 26,5 & 40,9 & 17,8 \\
\hline Czech Republic & 26 & 18,6 & 5,5 & 21,6 & 5,9 \\
\hline Denmark & 25 & 51,1 & 5,3 & 21,0 & 6,0 \\
\hline \begin{tabular}{|l|} 
Estonia \\
\end{tabular} & 32 & 25,8 & 9,1 & 23,6 & 11,7 \\
\hline \begin{tabular}{|l|} 
Finland \\
\end{tabular} & 26 & 48,7 & 5,5 & 21,5 & 6,6 \\
\hline France & 31 & 65,0 & 7,4 & 25,5 & 8,0 \\
\hline Greece & 34 & 40,0 & 12,6 & 24,4 & 15,2 \\
\hline Spain & 34 & 44,1 & 13,8 & 24,6 & 15,1 \\
\hline Netherlands & 28 & 47,9 & 6,6 & 22,7 & 7,8 \\
\hline Iceland & 25 & 45,0 & 5,6 & 20,9 & 5,9 \\
\hline Ireland & 30 & 47,0 & 7,7 & 23,3 & 9,7 \\
\hline Israel & 38 & 42,9 & 12,5 & 25,6 & 20,9 \\
\hline Japan & 34 & 36,9 & 10,7 & 24,4 & 16,0 \\
\hline Canada & 32 & 40,8 & 8,5 & 24,2 & 11,7 \\
\hline South Korea & 31 & 34,4 & 10,2 & 22,3 & 14,6 \\
\hline Luxembourg & 28 & 42,3 & 5,9 & 22,0 & 8,1 \\
\hline Mexico & 48 & 28,9 & 30,5 & 36,7 & 21,4 \\
\hline
\end{tabular}




\begin{tabular}{|c|c|c|c|c|c|}
\hline & $\begin{array}{c}\text { Gini } \\
\text { coefficient }\end{array}$ & $\begin{array}{l}\text { Taxes for } \\
\text { the richest }\end{array}$ & \begin{tabular}{|c|} 
The ratio of the \\
income of the \\
highest decile \\
group to the \\
income of the \\
lowest decile \\
group
\end{tabular} & $\begin{array}{l}\text { The share of } \\
\text { income of the } \\
\text { highest decile } \\
\text { group in total } \\
\text { income }\end{array}$ & $\begin{array}{c}\text { The income } \\
\text { poverty rate } \\
\text { (Relative } \\
\text { threshold) }\end{array}$ \\
\hline & \multicolumn{5}{|c|}{2011 or a later year available } \\
\hline Germany & 29 & 44,2 & 6,9 & 23,7 & 8,7 \\
\hline New Zeland & 32 & 33,0 & 8,0 & 24,7 & 9,8 \\
\hline Norway & 25 & 49,8 & 6,1 & 20,5 & 7,7 \\
\hline Poland & 30 & 35,5 & 7,7 & 23,5 & 11,1 \\
\hline Portugal & 34 & 48,0 & 9,9 & 26,7 & 11,9 \\
\hline Slovakia & 26 & 20,9 & 5,8 & 20,5 & 8,3 \\
\hline Sweden & 27 & 50,0 & 6,3 & 21,8 & 9,7 \\
\hline Switzerland & 29 & 32,6 & 6,9 & 23,0 & 10,3 \\
\hline Turkey & 41 & 35,0 & 15,2 & 31,7 & 19,2 \\
\hline USA & 39 & 30,5 & 16,5 & 28,4 & 17,4 \\
\hline Hungary & 29 & 29,9 & 7,3 & 22,5 & 10,4 \\
\hline UK & 34 & 42,8 & 9,6 & 27,6 & 9,5 \\
\hline Italy & 32 & 52,0 & 10,2 & 24,4 & 12,6 \\
\hline Maximum & 50 & 65 & 30,5 & 40,9 & 21,4 \\
\hline Minimum & 25 & 18,6 & 5,3 & 20,5 & 5,9 \\
\hline Mean & 31,7 & 40,3 & 9,7 & 24,6 & 11,6 \\
\hline Stand. Dev. & 6,0 & 9,9 & 5,7 & 4,4 & 4,3 \\
\hline Coefficient of variability & 19,2 & 24,6 & 27,3 & 18,0 & 37,3 \\
\hline
\end{tabular}

Source: OECD database http://stats.oecd.org/Index.aspx?DataSetCode=IDD report, KPMG's Individual Income Tax and Social Security Rate Survey 2012, pp. 10-11.

Each variable value shows a large and very large variation (over 10\%). Moreover, in order to analyze the data presented in Table 2, it is extremely difficult to observe any trends or similarities, or make a classification of countries into relatively homogeneous groups.

\section{Calculation of correlation and further elimination of indi-} cators: The next step in the construction of the ranking is to eliminate variables by examining the correlation between indicators. This method is intended to exclude these indicators from the set of indicators which carry the same information. The procedure is carried out by the method of reverse correlation matrix (A. Młodak, 2006, p. 31). Based on calculations, no variable was excluded from the set.

\section{The division of indicators into stimulants and destimulants:} One of the elements of TOPSIS method is to identify the set of indicators that stimulate and destimulate stratification. As the name implies, stimulants contribute to the expansion of stratification of income (their growth 
testifies to the growth of the variable), while destimulants act as a brake on the featured unit (their increase indicates a decline of the variable).

5. Calculation of synthetic measure: Indicators collected for testing are expressed by different units and assume the values of the various compartments of figures. If they are to be comparable (comparability of variables postulate) they must be unified through standardization, which takes place in accordance with the formulas (Roszkowska E. et. al., 2014, p. 82):

- for stimulants

- for destimulants

$$
z_{i k}=\frac{x_{i k}-\min _{i}\left\{x_{i k}\right\}}{\max _{i}\left\{x_{i k}\right\}-\min _{i}\left\{x_{i k}\right\}}
$$

where:

$$
z_{i k}=\frac{\max _{i}\left\{x_{i k}\right\}-x_{i k}}{\max _{i}\left\{x_{i k}\right\}-\min _{i}\left\{x_{i k}\right\}}
$$

$i$ - number of country OECD $(i=1,2,3, \ldots, n=33)$,

$k$ - number of indicator $(k=1,2,3, \ldots, m=5)$,

$\max _{i}\left\{x_{i k}\right\}$ - max. value of $k$-of this indicator,

$\min _{i}^{i}\left\{x_{i k}\right\}$ - minimum value of $k$-of this indicator.

Then the distances (Euclidean) are calculated of the countries of the OECD from the model $w^{+}=(1,1, \ldots, 1)$ and anti-model $w^{-}=(0,0, \ldots, 0)$ of stratification, according to the formula:

$$
d_{i}^{+}=\sqrt{\sum_{k=1}^{m}\left(z_{i k}-w_{k}^{+}\right)^{2}} \quad \text { i } \quad d_{i}^{-}=\sqrt{\sum_{k=1}^{m}\left(z_{i k}-w_{k}^{-}\right)^{2}}
$$

Finally, the calculation of the synthetic indicator of stratification proceeds according to the formula: $q=\frac{d_{i}^{-}}{d_{i}^{-}+d_{i}^{+}}$, for $i=1,2, \ldots, n=5$. The value of synthetic index ranges between 0 and 1 - the closer the value to 1 , the higher the position of $i$-state in the ranking.

After determining the value of the synthetic indicator for each state, it can be used for linear alignment of the analyzed units. This measure will classify the country into four classes using the arithmetic mean $\bar{q}$ and standard deviation of $S(q)$ the synthetic indicator:

Class I (high level): $q_{i} \geq \bar{q}+S(q)$

Class II (average higher level): $\bar{q} \leq q_{i}<\bar{q}+S(q)$

Class III (average lower level): $\bar{q}-S(q) \leq q_{i}<\bar{q}$

Class IV (low level): $q_{i}<\bar{q}+S(q)$ 
According to the adopted methodology, the ranking of OECD countries based on data from the years 2011-2013, has the following form:

Table 3

\section{Ranking of OECD countries due to the stratification of income}

\begin{tabular}{|c|c|c|c|c|c|c|c|c|}
\hline $\begin{array}{c}\text { Position } \\
\text { in the } \\
\text { ranking }\end{array}$ & OECD country & $\begin{array}{l}\text { Value of } \\
\text { indicator }\end{array}$ & Class & $\begin{array}{c}\text { Gini } \\
\text { coefficient* }\end{array}$ & Taxes* & \begin{tabular}{|c|} 
The ratio \\
of the \\
income of \\
the highest \\
decile group \\
to the in- \\
come of \\
the lowest \\
decile \\
group*
\end{tabular} & $\begin{array}{l}\text { The share } \\
\text { of income } \\
\text { of the } \\
\text { highest } \\
\text { decile } \\
\text { group in } \\
\text { total } \\
\text { income* }\end{array}$ & $\begin{array}{l}\text { The income } \\
\text { poverty rate } \\
\text { (relative } \\
\text { threshold)* }\end{array}$ \\
\hline 1 & Chile & 0,72 & 1 & \multirow{5}{*}{43} & \multirow{5}{*}{34} & \multirow{5}{*}{20,24} & \multirow{5}{*}{32,66} & \multirow{5}{*}{19,34} \\
\hline 2 & Mexico & 0,70 & 1 & & & & & \\
\hline 3 & Turkey & 0,66 & 1 & & & & & \\
\hline 4 & USA & 0,60 & 1 & & & & & \\
\hline 5 & Israel & 0,59 & 1 & & & & & \\
\hline 6 & Japan & 0,52 & 2 & \multirow{13}{*}{33} & \multirow{13}{*}{37} & \multirow{13}{*}{10,22} & \multirow{13}{*}{23,82} & \multirow{13}{*}{14,26} \\
\hline 7 & Estonia & 0,50 & 2 & & & & & \\
\hline 8 & Australia & 0,49 & 2 & & & & & \\
\hline 9 & Greece & 0,48 & 2 & & & & & \\
\hline 10 & South Korea & 0,47 & 2 & & & & & \\
\hline 11 & New Zeland & 0,46 & 2 & & & & & \\
\hline 12 & Spain & 0,45 & 2 & & & & & \\
\hline 13 & UK & 0,45 & 2 & & & & & \\
\hline 14 & Portugal & 0,45 & 2 & & & & & \\
\hline 15 & Canada & 0,45 & 2 & & & & & \\
\hline 16 & Hungary & 0,45 & 2 & & & & & \\
\hline 17 & Poland & 0,44 & 2 & & & & & \\
\hline 18 & Switzerland & 0,44 & 2 & & & & & \\
\hline 19 & Slovakia & 0,43 & 3 & \multirow{9}{*}{29} & \multirow{9}{*}{41} & \multirow{9}{*}{7,22} & \multirow{9}{*}{22,70} & \multirow{9}{*}{9,04} \\
\hline 20 & Czech Republic & 0,42 & 3 & & & & & \\
\hline 21 & Italy & 0,40 & 3 & & & & & \\
\hline 22 & Germany & 0,38 & 3 & & & & & \\
\hline 23 & Ireland & 0,38 & 3 & & & & & \\
\hline 24 & Austria & 0,37 & 3 & & & & & \\
\hline 25 & Luxembourg & 0,36 & 3 & & & & & \\
\hline 26 & Sweden & 0,33 & 3 & & & & & \\
\hline 27 & Netherlands & 0,33 & 3 & & & & & \\
\hline 28 & France & 0,31 & 4 & \multirow{6}{*}{27} & \multirow{6}{*}{52} & \multirow{6}{*}{6,08} & \multirow{6}{*}{21,84} & \multirow{6}{*}{7,54} \\
\hline 29 & Belgium & 0,31 & 4 & & & & & \\
\hline 30 & Finland & 0,30 & 4 & & & & & \\
\hline 31 & Iceland & 0,29 & 4 & & & & & \\
\hline 32 & Norway & 0,28 & 4 & & & & & \\
\hline 33 & Denmark & 0,27 & 4 & & & & & \\
\hline
\end{tabular}

* the arithmetic average of the indicators within the class of countries

Source: own calculations. 


\section{Summary and conclusions}

With the aggregation of individual variables relating to the stratification of income in one synthetic indicator, it is easier to draw constructive conclusions, comparing each individual class, about countries in terms of differences in the presented variables.

The first important finding resulting from Table 3 is the extremely high position of developed countries, i.e. the US and Israel just below Chile, Mexico, and Turkey opening the ranking. All these countries form the first class of countries with the highest value of synthetic indicator and thus the countries with the greatest economic diversity. This confirms the observations made by both R. Wilkinson and Picket K., T. Piketty and J. Stiglitz, who pointed out in their studies the growing gap between rich individuals and society in the richest country in the world.

Secondly, it shows the scale of the disparities of averaged indicators between the first class countries (Chile, Mexico, Turkey, USA, Israel) and the countries of the fourth class (Denmark, Norway, Iceland, Finland, Belgium, France). The difference in the Gini coefficient is as high as 16 points, the divergence of taxes the richest pay reaches $18 \%$, the ratio of the income of the highest decile group to the lowest decile group differs by more than 14 points.

It is therefore worth looking closer at the tax and social systems of countries of the fourth class, where out of the six, half are Scandinavian countries (Denmark, Norway and Finland), and consider to what degree the solution would be possible to use in other countries.

What is important, the above countries, apart from the clearly smaller stratification of income, are significantly better in terms of social indicators, health, education indicators, concerning e.g. social trust, the status of women, assistance to the needy, obesity, average test scores in math, social mobility. Much less socially acceptable is consumption to show off and competition for status (R. Wilkinson, K. Pickett, 2009).

This is not only a question of wealth of these countries, which undoubtedly belong to the forefront of the richest in the world, because, for example, the US has an even higher national income per capita, and yet is on the opposite end of the rankings, every year exacerbating the disparities described.

\section{N O T E S}

${ }^{1}$ http://www.epi.org/publication/ceo-pay-continues-to-rise/ [access: 03.11.2015]. 
2 Shadow Banking - European Commission document Green Paper on Shadow Banking adopted the definition of shadow banking as "a system of credit intermediation that involves entities and activities outside the regular banking system".

3 Oxfam is an international humanitarian organization dedicated to the fight against world hunger and providing assistance in developing countries. In 2002, the confederation consisted of 12 organizations.

${ }^{4}$ Por. Working for the few. Political capture and economic inequality, 2014, p. 2.

${ }^{5}$ http://stats.oecd.org/Index.aspx?DataSetCode=IDD.

${ }^{6}$ KPMG's Individual Income Tax and Social Security Rate Survey 2012, pp. 10-11.

\section{R E F E R E N C E S}

Alvaredo, F., Atkinson, A. B., Piketty, T., \& Saez, E. (2013). The Top 1 Percent in International and Historical Perspective. Journal of Economic Perspectives, 27(3), 3-20. http://doi.org/10.1257/jep.27.3.3

Cowell, F. A. (2011). Measuring inequality (3rd ed). Oxford: Oxford University Press.

Galbraith, J. K. (2007). Global inequality and global macroeconomics. Journal of Policy Modeling, 29(4), 587-607. http://doi.org/10.1016/j.jpolmod.2007.05. 008

Hwang, C.L., Yoon, K. (1981). Multiple Attribute Decision Making: Methods and Applications. New York: Springer-Verlag

Kęcik, K. (2012, March 8). Bomba zegarowa Regana. Tygodnik Przegląd. Retrieved from http://www.tygodnikprzeglad.pl/bomba-zegarowa-reagana/

Klein, N. (2010). No logo: no space, no choice, no jobs (10th anniversary ed., 3rd ed). New York: Picador.

Krugman, P. R. (2009). The return of depression economics and the crisis of 2008. New York: W.W. Norton.

Lal, D., Lang, J., Balcerowicz, L., \& Zysk i S-ka Wydawnictwo. (2015). Ubóstwo a postęp: ubóstwo na świecie: fakty i mity. Poznań: Zysk i S-ka Wydawnictwo.

Lambert, P. J. (2001). The distribution and redistribution of income (3rd ed). Manchester; New York: New York: Manchester University Press; Distributed exclusively in the USA by Palgrave.

Lissowski, G., Haman, J., \& Jasiński, M. (2008). Podstawy statystyki dla socjologów. Warszawa: Wydawnictwo Naukowe Scholar.

Młodak, A. (2006). Analiza taksonomiczna w statystyce regionalnej. Warszawa: Centrum Doradztwa i Informacji Difin.

Piketty, T., Bilik, A., Sutowski, M., \& Wydawnictwo Krytyki Politycznej. (2015). Kapitał w XXI wieku. Warszawa: Wydawnictwo Krytyki Politycznej. 
Piketty, T., \& Goldhammer, A. (2014). Capital in the twenty-first century. Cambridge Massachusetts: The Belknap Press of Harvard University Press.

Roszkowska, E., Misiewicz, E. I., \& Karwowska, R. (2014). Analiza poziomu zrównoważonego rozwoju województw Polski w 2010 roku. Ekonomia i Środowisko, Czasopismo Polskiego Stowarzyszenia Ekonomistów Środowiska i Zasobów Naturalnych, (2 (49)), 182.

Shorrocks, A. F. (1980). The Class of Additively Decomposable Inequality Measures. Econometrica, 48(3), 613. http://doi.org/10.2307/1913126

Silber, J. (2003). Gary S. Fields, Distribution and Development, A New Look at the Developing World. Journal of Development Economics, 70(1), 238-243. http://doi.org/10.1016/S0304-3878(02)00025-1

Stiglitz, J. E. (2013). The price of inequality. New York: W. W. Norton \& Company.

Tarentino, A. L., \& Maley, F. (1975). A comparison of the substrate specificities of endo-beta-N-acetylglucosaminidases from Streptomyces griseus and Diplococcus Pneumoniae. Biochemical and Biophysical Research Communications, 67(1), 455-462.

Therborn, G. (2013). The killing fields of inequality. Cambridge: Polity Press.

Trzaskalik, T. (2014). Wielokryterialne wspomaganie decyzji. Przegląd metod i zastosowań. Zeszyty Naukowe Politechniki Śląskiej, z. 74(1921), 239-263.

Tucker, I. B. (2011). Survey of economics (7th ed). Mason, OH: South-Western Cengage Learning.

Wilkinson, R., \& Pickett, K. (2009). The spirit level: why more equal societies almost always do better. London: Allen Lane.

Woźniak, W. (2013). Nierówności w publicznej debacie. Zmierzch neoliberalnej mitologii? Władza sądzenia, (2), 45-54. 